\title{
Beyond the research paper First-generation students and the Framework in everyday contexts
}

B eing first gen, it's hard, like, the library information is not in us 'cause we are learning this by ourselves." This sentiment, expressed by Vanessa, a first-year, first-generation student, is a common one. The unspoken norms, procedures, and genres that incoming students are expected to grasp—both in higher education generally and in information literacy and academic libraries specifically—often make college an unfamiliar, confusing, and unwelcoming new world for first-generation students (FGS). Yet in my work as a liaison librarian for $\mathrm{TRIO}^{1}$ and other support programs at the University of Northern Colorado, I constantly wonder at the highly developed and varied knowledge and skills FGS bring with them from their homes, workplaces, communities, and previous education.

In response to the prevalent deficit understanding of FGS, even among students themselves, I undertook a research project in which several FGS and I together uncovered and explored the ways that they work with information in their everyday lives. This counters much of the LIS literature on FGS in two ways. First, the focus has traditionally been on academic contexts, either on coursework (particularly research papers) or on college-specific situations, such as advising or registering for courses. ${ }^{2}$ Second, and related to the narrow academic focus, FGS have been framed as lacking the knowledge and skills to complete college successfully. Studies often begin with a list of negative statistics concerning retention and graduation and descriptions of FGS as at-risk for failure. ${ }^{3}$ Yet as a recent critic of the deficit perspective points out, FGS have many strengths that they bring with them to college. ${ }^{4}$ In fact, there is a growing trend in LIS of using asset-based pedagogies - those that emphasize the strengths that students bring with them to formal education-to work with underrepresented and underserved students. ${ }^{5}$ What emerged from my conversations with FGS was a sense of their everyday information literacy knowledge practices and dispositions, which can inform our practice as library educators.

\section{The study ${ }^{6}$}

Six students volunteered for one-on-one interviews with me. Each chose a pseudonym for the project. I knew all of them from collaborating with their FGS programs. The demographics reflected the makeup of the TRIO programs: five were Latinx/Hispanic, and one was Black; four were women, and two were men; their ages were from 18 to 21 ; and they ranged from first-years to juniors. I did not ask about socioeconomic status, but the majority of students in the FGS programs are from low-income backgrounds. Though the students and I share first-generation status and

Darren llett is information literacy librarian at the University of Northern Colorado, email: darren. ilett@unco.edu

(c) 2020 Darren llett 
working-class backgrounds, as a white man and as the librarian for their program, I strove to remain aware of my privilege and power during and after the conversations. As a form of relational research practice and a sign of gratitude for their time and knowledge, I offered them a drink and snack of their choice from a coffee cart in the library. I also offered students the opportunity to review my findings as a member check to confirm their accuracy. Five of the six responded and agreed that my representations of them were accurate.

\section{Connections to the Framework}

An unanticipated and exciting discovery that resulted from the conversations was the strong connection between the Framework for Information Literacy for Higher Education and students' engagement with information in household, work, and community contexts. While there were connections to all six frames, here I will focus on three students and the ways in which their everyday information literacy resonates with several of the frames. These examples demonstrate the type and breadth of students' knowledge practices and dispositions, as well as ways to bridge academic and nonacademic contexts.

\section{Vanessa: Debating with peers}

A first-year student, Vanessa reported that she began monitoring her own reaction to information after encountering the concept of confirmation bias in a psychology course: "I've read things that, I'm like, 'No, it's not right!', 'cause it's my personal beliefs being attacked, you know?" To counteract the tendency to reject information that did not coincide with her beliefs, Vanessa made sure to seek varying viewpoints: "I learn about what I'm agreeing with. I like learning about that, but I also like learning about the things that contradict it because I think, especially with debating, you have to do both sides of it." Vanessa's learning about the multiple sides of issues took place both within and outside the classroom. In fact, much of what she was debating with fellow students had to do with her identity as a Latina, including historical figures (including César Chávez) and terms (such as Chicano) she had newly learned about at the Latinx cultural center. Her openness to others' sometimes contradictory viewpoints helped foster an atmosphere of respectful debate in the campus community.

As Vanessa developed a sense of her own identity and learned more about the history of the communities to which she belonged, she also demonstrated dispositions outlined in the Authority Is Constructed and Contextual frame, such as skepticism, self-awareness of one's own perspectives, and openness to varying viewpoints. ${ }^{7}$ In fact, she described how actively seeking information with which she disagreed fostered an awareness of her own biases. Vanessa's example shows FGS as curious, open to new experiences and viewpoints, increasingly self-aware as they enter new social and intellectual environments on campus and in the community, and interested in topics related to their identities, which they are often exploring and understanding in new ways as they begin college.

\section{Maria: Seeking help in college and beyond}

Maria, also a first-year student, explained that she chose not to seek assistance with her coursework from her family: "I know that my family won't be able to help me out because for the simple fact that none of them have gone to college." Maria recognized that, because of persistent barriers to higher education based on systemic issues such as racism and economic injustice, her family was among those excluded from the production and dissemination of information. When doing research for her college courses, Maria instead went to people who have "more background in the specific topic," such as her instructors. Yet Maria also went on to stress that her family was indeed able to provide her with trustworthy, relevant information in other contexts, such as how to deal with the aftermath of a car accident and how to find an attorney. Further, she sought information about becoming a swim instructor from her employer and developed her swimming and instruction skills by watching online videos and trying out tech- 
niques herself.

Maria's recognition of the marginalization of her family from the production of information corresponds to a knowledge practice in the Information Has Value frame. ${ }^{8}$ In addition, the practice of turning to her instructors for assistance with coursework reflects the disposition in the Searching as Strategic Exploration frame regarding seeking help from experts. ${ }^{9}$ Finally, Maria identified different kinds of authority and then sought appropriate sources of help based on context and the kind of information she was seeking, whether it was in the home, the workplace, online, or in the classroom. This corresponds to a knowledge practice concerning various kinds of authority based on subject expertise, societal position, or special experience in the Authority Is Constructed and Contextual frame. ${ }^{10}$ Maria's comments show FGS as both highly aware of injustices related to the information economy and higher education, as well as adept at determining the relevant type of authority and at seeking appropriate help in various everyday and academic contexts.

\section{Brady: Taking part in multiple conversations}

A junior, Brady described his participation in conversations online. Regarding social media, he remarked that, "I think it's really cool to see other people and see how they're dealing with their whole situation," particularly relating to their sexuality. Yet Brady expressed ambivalence about his own social media presence. On the one hand, he voiced some hesitation in posting directly about having recently come out: "I don't necessarily go out of my way to say things to, like, push things onto people." On the other hand, he argued that "You have the ability to make a Tweet or something like that, and it can go viral because people respond to it, right?" The possibility of impacting a large audience both appealed to and concerned Brady. In addition to social media, he published an article related to his Latino heritage in an undergraduate research journal. Brady thus took part in conversations related to his identities in various forums, both formal and informal. ${ }^{11}$

Aligning with the knowledge practice of contributing to (scholarly) conversations in the Scholarship as Conversation frame, Brady found multiple venues to engage in conversations of varying registers, as both a consumer and a contributor. Brady's case exemplifies FGS as engaged in meaningful conversations at various levels of formality and able to adjust their tone and information use accordingly. They are constantly reading and writing, particularly via social media and particularly in relation to issues that speak to their communities.

\section{Implications for IL instruction}

The everyday engagement with information that Vanessa, Maria, and Brady described is not atypical. In my work with TRIO and other support programs, I often observe students' curiosity, openness, skepticism, self-awareness of their own biases, and attention to injustices relating to access to information and scholarship. Further, FGS recognize various types of authority and seek help from appropriate sources accordingly. They also take part in academic and nonacademic conversations that matter to them, especially as they relate to their own experiences and identities.

Of course, all students display these characteristics to varying degrees, and many students, both FGS and continuing-generation, find college-level research challenging. As Vanessa's comments about the difficulty of learning to use the library on her own illustrate, FGS may internalize deficit thinking and consider themselves inadequate. That tendency may contribute to lower retention and graduation statistics. For these reasons, I believe that the way in which we librarians approach our work with FGS matters. How can we work with them to address the challenges of research and information literacy without reverting to notions of deficiency and remedial interventions?

My approach is to build on the tendencies that I have observed in working with them, that is, the knowledge practices and dispositions that they display in their everyday engagement with information. Those then serve as the foundation for instruction. I get to know them in a variety of ways, including attending their program's summer bridge 
program before their first semester, craft and holiday events, study nights, and research and creative presentations. When I see them in the library or the cafeteria, I check in with them. In my courses, I use private online surveys that ask about their interests and previous research experience. Their interests and experiences then serve as starting points for discussions and activities. In fact, they frequently choose research topics that relate to their own identities, experiences, and interests in social justice issues. In learning how and why to use library search tools, we highlight the connection to their use of search tools in their everyday lives to shop and to find information. We discuss various types of authority and expertise beyond academic credentials that they know of in their own lives, thus valuing and honoring the knowledge and skills they've learned from their families and communities. Relatedly, we consider who has access to information and whose voices are excluded from research.

As research has shown, the focus on students' assets can foster their intrinsic motivation to conduct research. ${ }^{12}$ Indeed, emphasizing students' everyday information literacy and connecting it to academic contexts can demonstrate to them the relevance of information literacy for their lives after college. Importantly, asset-based approaches have the advantage of calling on institutions of higher education, such as academic libraries, to change how we work rather than forcing FGS and other underrepresented and underserved students to conform to the norms of higher education that were designed without them in mind.

\section{"I'm just going to keep going!"}

Though we began with a barrier that Vanessa identified-the difficulty of learning all the library information necessary for success in coursework-she also explained that she wants to learn from her instructors and librarians. Vanessa ended by saying that, no matter what, "I'm just going to keep going!" The combination of knowledge practices and dispositions related to the framework that FGS displayed in my conversations with them make me confident that they will do just that.

\section{Notes}

1. TRIO is a suite of federally funded programs designed to foster the academic success of FGS. See U.S. Department of Education, "Federal TRIO Programs: Home Page," https://www2.ed.gov/about/offices/list/ope /trio/index.html (accessed March 11, 2020).

2. See, for example, Stacy Brinkman, Katie Gibson, and Jenny Presnell, "When the Helicopters are Silent: The Information Seeking Strategies of First-Generation College Students," in Imagine, Innovate, Inspire: Proceedings of the ACRL 2013 Conference, ed. Dawn M. Mueller (Chicago: Association of College and Research Libraries, 2013), 643650; Firouzeh Logan and Elizabeth Pickard, "First-Generation College Students: A Sketch of their Research Process," in College Libraries and Student Culture: What we Now Know, eds. by Lynda M. Duke and Andrew D. Asher (Chicago: American Library Association, 2012), 109-125.

3. Examples include Catherine Haras and Suzanne L. McEvoy, "Making the Bridge: Testing a Library Workshop for a Summer Bridge Learning Community," Research Strategies 20, no. 4 (2007): 258, https://doi.org/10.1016/j. resstr.2006.12.003; Tien-I Tsai, "CourseworkRelated Information Horizons of First-Generation College Students," Information Research 17, no. 4 (2012), http://www.informationr. net/ir/17-4/paper542.html\#.Wp28kGaZOV4.

4. Anne Jumonville Graf, "First-Generation Students and Libraries: Beyond the Deficit Narrative," in Supporting Today's Students in the Library: Strategies for Retaining and Graduating International, Transfer, FirstGeneration, and Re-Entry Students, eds. Ngoc-Yen Tran and Silke Higgins (Chicago: Association of College and Research Libraries, 2020), 15.

5. See, for example, Amanda L. Folk, "Drawing on Students' Funds of Knowledge: Using

(continues on page 297) 
challenges when trying to gather information from faculty about their courses. We hope to build on this positive partnership.

Additionally, we continue to have strong support from library administration. Our vice provost and director provided us with a small amount of funding for lunches and refreshments at our workshops, and she gave the introductory remarks at one of our workshops. We expect this continued support from our administration, the recent passage of student legislation, and our new open education librarian position to push the conversation about OER to the next level on the UT-Austin campus.

\section{Acknowledgements}

Special thanks to all the OER Outreach group members-Hannah Chapman-Tripp, Carolyn Cunningham, Lea DeForest, Lydia Fletcher, Amanda Hager, Natalie Hill, Nathalie Steinfeld Childre, and Sarah Sweeney.

\section{Notes}

1. SPARC, "Open Education," accessed March 26, 2020, https://sparcopen.org/open -education/.

2. The University of Texas at Austin Institutional Reporting, Research, and Information Systems, "UT Austin by the Numbers," accessed March 26, 2020, https://reports. utexas.edu/.

3. Center for Open Educational Resources and Language Learning (COERLL), accessed March 26, 2020, https://www.coerll.utexas. edu/coerll/.

4. Lindsay McKenzie, "Inclusive Access Takes Off," Inside Higher Ed, November 7, 2017, https://www.insidehighered.com /news/2017/11/07/inclusive-access-takes -model-college-textbook-sales.

5. Texas Digital Library, "About TDL," accessed April 1, 2020, https://www.tdl.org /about-tdl/.

6. Texas Digital Library, "Texas OER Summit for Academic Libraries," accessed April 1, 2020, https://www.tdl.org/2018/09/texas -oer-summit-for-academic-libraries/.

7. Open Education Global, "What is Open Education Week," accessed March 26, 2020, https://www.openeducationweek.org/page /what-is-open-education-week.

8. University of Texas Libraries, "Open Education Week Posts," TexLibris (blog), March 2018, https://texlibris.lib.utexas.edu /tag/open-education-week/.

9. Reality Czech, accessed March 27, 2020, https://realityczech.org/.

10. Gina Bastone, et al., "Talkin' 'Bout OER,” Texas ScholarWorks (institutional repository), October 2018, http://hdl.handle. net/2152/69099.

11. The University of Texas System, "Previous Recommendations," 2005-2015, https://utsystem.edu/offices/academic -affairs/previous-recommendations. $\boldsymbol{n}$

("First-generation students . . .," continues from page 288)

Identity and Lived Experience to Join the Conversation in Research Assignments, Journal of Information Literacy 12, no. 2 (2018): 44-59, https://doi.org/10.11645/12.2.2468; Kim L. Morrison, "Informed Asset-Based Pedagogy: Coming Correct, Counter-Stories from an Information Literacy Classroom," Library Trends 66, no. 2 (2017): 176-218, https://doi.org/10.1353/lib.2017.0034.

6. For a fuller description of the study, see Darren Ilett, "First-Generation Students' Information Literacy in Everyday Contexts," Journal of Information Lit- eracy 12, no. 2: 73-91, https://dx.doi. org/10.11645/13.2.2675.

7. ACRL, "Framework for Information Literacy for Higher Education" (Chicago: Association of College \& Research Libraries, 2015): 13, www.ala.org/acrl/sites/ala.org.acrl /files/content/issues/infolit/framework1.pdf.

8. Ibid., 16.

9. Ibid., 23.

10. Ibid., 12.

11. Ibid., 20.

12. Folk, "Drawing on Students' Funds of Knowledge," 55. n 